\title{
Business Model Development Strategy of Padjadjaran University with Canvas Business Model Approach
}

\section{Budi Mulyana ${ }^{1}$ ¿ Arief Daryanto ${ }^{2}$ Agus Purwitos}

'School of Business, Bogor Agricultural University Jl. Raya Pajajaran, Bogor 16151; University of Padjadjaran Jl. Bandung - Sumedang Km. 21 Jatinangor Sumedang, Indonesia Email:budi@unpad.ac.id Tel:+628172357911

${ }^{2}$ School of Business, Bogor Agricultural University Jl. Raya Pajajaran, Bogor 16151, Indonesia Email: adarvant@yahoo.com Tel: +628129997947

${ }^{s}$ Department of Agronomy \& Horticulture, Faculty of Agriculture, Bogor Agricultural University, Dramaga Bogor 16680, Jawa Barat, Indonesia

Email:apurwito@yahoo.com Tel:+62811116228

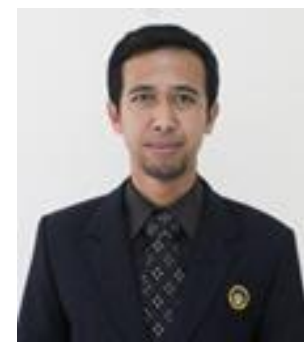

Corresponding Author)

Theck for updates

\begin{abstract}
Governments' policy regarding pattern alteration from general university management into a legal incorporated higher education institution, forced the Padjadjaran University to be more creative in finding other revenue stream in order to maintain the university sustainability. This study aims are to identify the business model of PTN BLU and PTN BH; and develop a business model development strategy. This study conducted with an in-depth interview approach to top management. Data were analyzed using nine building block of business model canvas and SWOT analysis. The result of this study revealed that the university need to apply a combination of free business models and joint business models to generate other income streams but still prioritize the idealism to educate the life of the nation. Other revenue streams are obtained by commercializing the results of research with licensed business models.
\end{abstract}

Keywords: Business model canvas, Higher education, Public higher education institution as legal entity, Public higher education institution as public service entity, Analysis business model higher education.

JEL Classification: F44, O10

\section{Introduction}

Decree number 20 Year 2003 regarding national education system mentioned that higher education institution determined their own policy and possessed autonomy in organizing education within the institution (Setneg, 2003). Moreover, Higher Education Decree number 12 year 2012, every higher education institution have the autonomy to organize themselves as Tridharma implementation center in accordance to the basic, purpose and ability of the institution (Setneg, 2012). Autonomy referred in the decree was academic field which consisted of determination of norm, operational policy and Tridharma implementation; as well as non-academic field which consisted of determination of norm, operational policy and organizational administration, financing, students' affair, employment, facilities and infrastructure. Based on Government Regulation of Republic of Indonesia number 4 year 2014, the management pattern of public HEIs (PTN) consisted of PTN with general financial management pattern or called as work unit PTN (PTN Satker); PTN with public service entity management pattern (PTN BLU); and PTN as legal entity (PTN BH) (Setneg, 2014). University of Padjadjaran (UNPAD) had experienced management pattern shifting from PTN BLU into PTN BH in 2017 after having two years of transition period and also fulfill the requirements as PTN BH based on the criteria set by Ministry of Research, Technology and Higher Education (Kemenristekdikti, 2016).

Governments' Institution Performance Report (LAKIP) of UNPAD of 2015 noted that the total amount of community fund (DM) revenue from 2013 to 2015 were having a fluctuation. The total of community fund (DM) revenue collected in 2013 was 576 billion Rupiah, while community fund revenue in 2014 recorded as much as 480 billion Rupiah, and DM revenue in 2015 was 522 billion Rupiah. Those things indicated that UNPAD need to increase their revenue stream through value propositions invention in terms of a business model. Business model is a method in conducting business so that the institution could generate revenues to maintain the organization sustainability. According to Osterwalder and Pigneur (2010) the motivation in conducting business model innovation for an on-going organization were as follow: problems occur in present business model, adaptation to changing environment, presenting product and technology into the market or preparing a new business model. Business Model Canvas (BMC) is logical illustration regarding how the organization inventing, delivering and capture a value (Osterwalder and Pigneur, 2010). The purpose of this study as follow:

1. Identifying UNPAD PTN BLU business model with BMC approach. 
2. Identifying UNPAD PTN BH business model with BMC approach.

3. Analyzing business model improvement with BMC approach.

\section{Methodology}

This study took place in University of Padjadjaran located in Jl. Bandung Sumedang KM. 21 Jatinangor Sumedang. This study was conducted since April 2017 until January 2018. Research methodology used in this study was qualitative descriptive method by using case studies. Primary data obtained from an in-depth interview with the respondents. Secondary data used obtained from various sources i.e. financial reports, UNPAD in numbers, books, journals, regulations, legislations and other relevant data sources.

\subsection{Data Processing and Analyses Technique}

The main analysis tool used to reveal and describe UNPAD business model was BMS nine building blocks adopted from nine building block of business model canvas (Osterwalder and Pigneur, 2010) and also SWOT analysis.

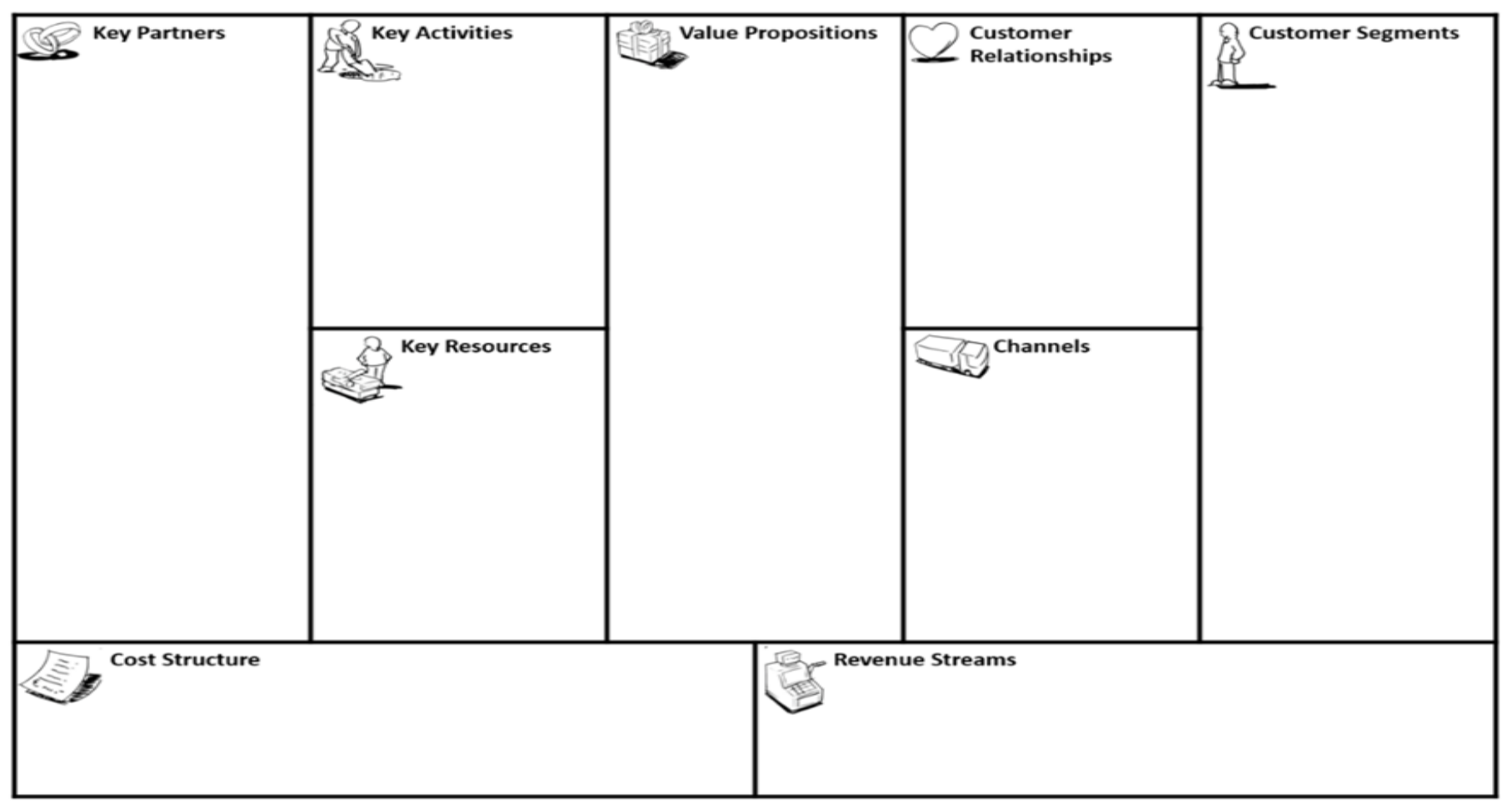

Picture-1. Nine building block of BMC (Osterwalder and Pigneur, 2010)

Customer segments described as a set of people or various organizations which desired to be reach or serve by higher education institution. Value propositions described various products and services which will create value for a certain customer segment. Channel described the way and place within a higher education institution to be able to communicate with their customers in presenting value propositions.

Customer relationship explained about maintaining relationship between higher education institution with the customer. Revenue streams described income or revenue in terms of cash accepted by higher education institution from every segment of customer. Key Resource described important assets which will be require to build the business model in a certain higher education institution. Key activities explain the most important thing to be done by higher education institution to make its business model runs well in creating products. Key partnership described supplier network and business partner that generate a running well business model. Cost structure explain the most important cost incurred to operate business model.

Data processing divided into three stages, as follow:

1. First stage, the data obtained from interviews, observation and documentation study processed through nine segments in BMC as the first stage to identify UNPAD business model with management pattern of PTN BLU and PTN BH as presented in Picture 1.

2. Second stage conducting analysis over identification result by using the SWOT analysis. SWOT analysis stage conducted to nine block BMC building in order to analyze UNPAD PTN BLU business model and UNPAD PTN BH business model.

3. Third stage, outcome data of SWOT analysis result created to be improvement of business model design income by using BMC approach.

\section{Discussion and Result}

\subsection{Topography of UNPAD PTN BLU Business Model}

Topography conducted in accordance to business model identification result to obtain a profound picture through PTN BLU management system implemented by UNPAD before experiencing transformation period of becoming PTN BH. The topography conducted by identifying nine blocks of BMC building presented in Picture 2.

Key partner of PTN BLU UNPAD is the government, as the regulations administrator and higher education policy creator. As PTN, the whole processes regarding any learning and students' affair, research, innovation, institutional and science and technology resources, being under Ministry of Research, Technology and Higher Education co-ordination. Learning, dedication to the community and research are included in building blocks of key activities. UNPAD for being favorite PTN, learning center, located in the city of Bandung, also as scientific 
field of law and community development are its value propositions. Learning and consultant process as the form of customer relationship. In the customer segment building block there are students and graduates users. The number of active UNPAD students' academic year of 2016 odd semester were as much as 37 thousand students, consisted of 27.465 students of undergraduate program, 3.118 students of graduate/magister program, 1.843 students of 3 years' diploma program, 1.663 students of doctoral program, 1.366 students of specialist program, 1.164 students of professional program and 483 students of diploma IV.

Infrastructure, government subsidy and lecturers are included in key resources. Channels block building consisted of national selection examination of public higher education institution admission (SNMPTN), joint selection examination of public higher education institution admission (SBMPTN) and admission test to University of Padjadjaran (SMUP), in accordance to Ministry of Research, Technology and Higher Education regulation number 126 year 2016 regarding new students admission of undergraduate program in public higher education institution (Kemenristekdikti, 2016). Meanwhile, in cost structure building block consisted of BLU form operational, infrastructure development, learning operational. State revenue and expenditure budget (APBN) and non-tax state income (PNBP) are PTN BLU UNPAD revenue streams.

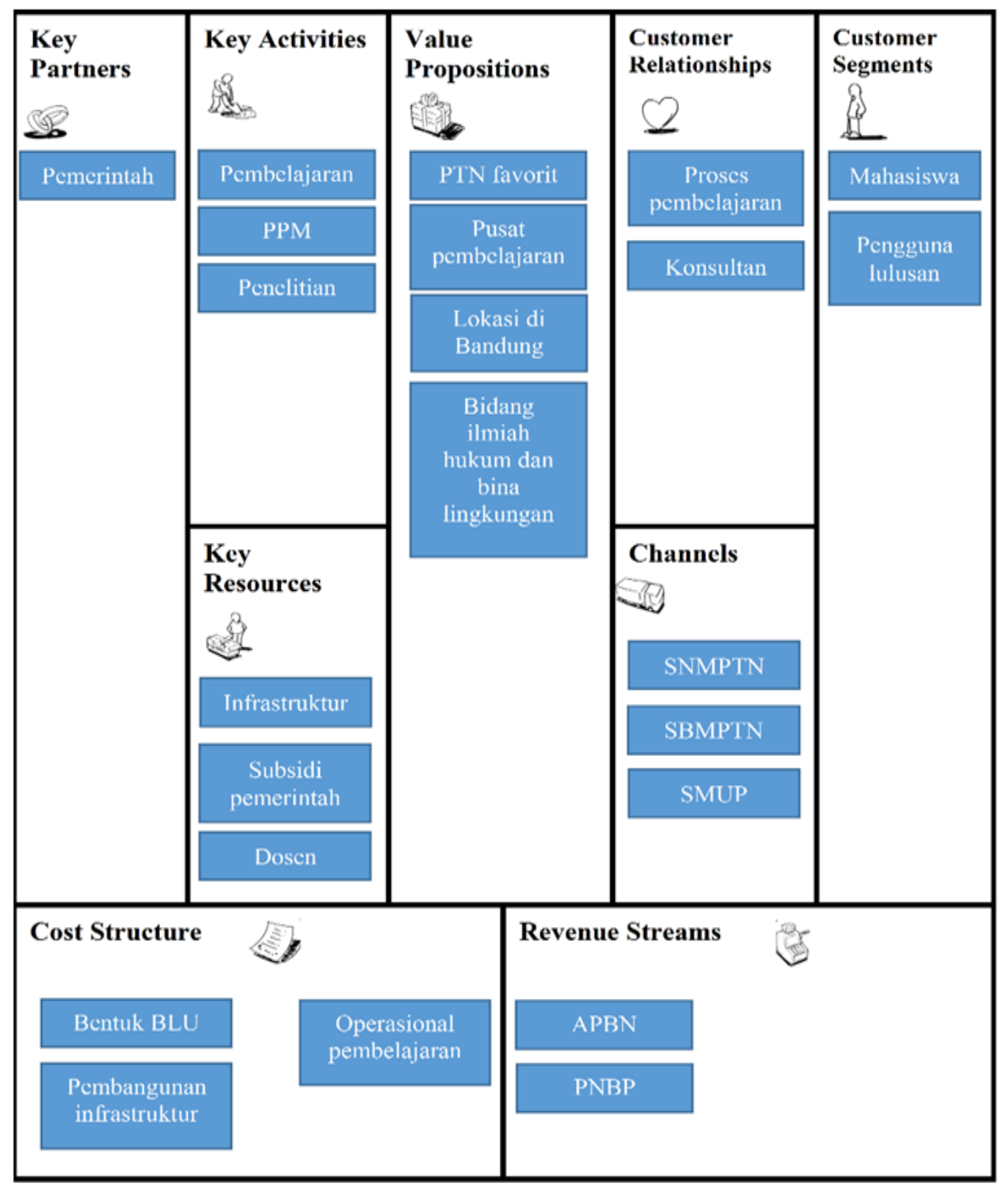

Source: Data field.

Picture-2. BMC PTN BLU UNPAD

\subsection{Topography of UNPAD PTN BH Business Model}

The topography conducted based on business model identification result to obtain profound picture of PTN BH management system currently conducted by UNPAD. The topography conducted by identifying nine blocks of BMC building presented in Picture 3.

Key partners building block consisted of two segments namely pentahelix and strategic partners. Pentahelix consisted of academic partner, business, community, government, media; while strategic partners include west java local government, Bandung city government, and state-owned enterprises (BUMN). Key activities building block consisted of research, dedication to the community and learning. Value proposition building block consisted of research university West Java based, scientific field of law and environment. Turning local government as research center and integrated service unit are the customer relationship building block. Customer segments consisted of students, academic staff, community, government and media. 


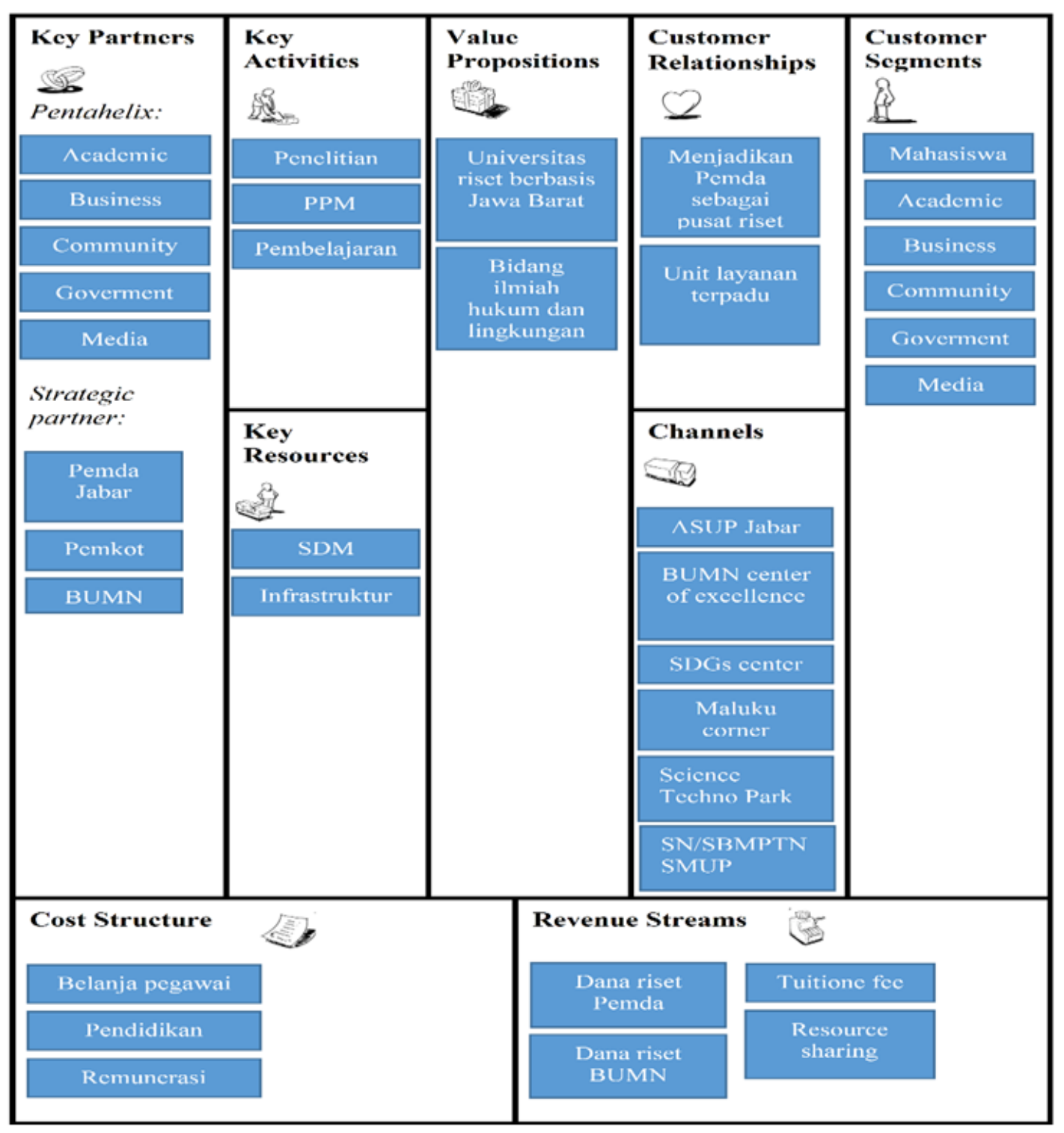

Source: Data field.

Picture-3. BMC of PTN BH UNPAD

Key resources building block consisted of human resources and infrastructure. Channels consisted of strategic alliance of university of Padjadjaran and West Java (ASUP West Java), state-owned enterprises (BUMN) center of excellence, sustainable development goals (SDGs) center, Maluku corner, science Techno Park and UNPAD Admission Test. Cost structure building block consisted of employee expenditure, BUMN research fund, tuition fee, resource sharing.

\subsection{Business Model Evaluation}

Model business improvement begins with evaluating business model using SWOT analysis. Business model evaluation used a tool called the tolo branca version V3.3, which is a SWOT analysis tool which specialized to be used to analyze BMC SWOT. Pictures 4 and 5 show a graphical overview the evaluation (Mulders and Broek, 2012). Picture 4 showed there was no business model building block colored red or required special attention at the moment of study. Value propositions and cost structure were colored green which means a good quality of UNPAD business model at the moment. Meanwhile the other building block with yellow color or require some improvements namely key partners, key activities, customer relationships, customer segments, key resources, channels and revenue streams. 


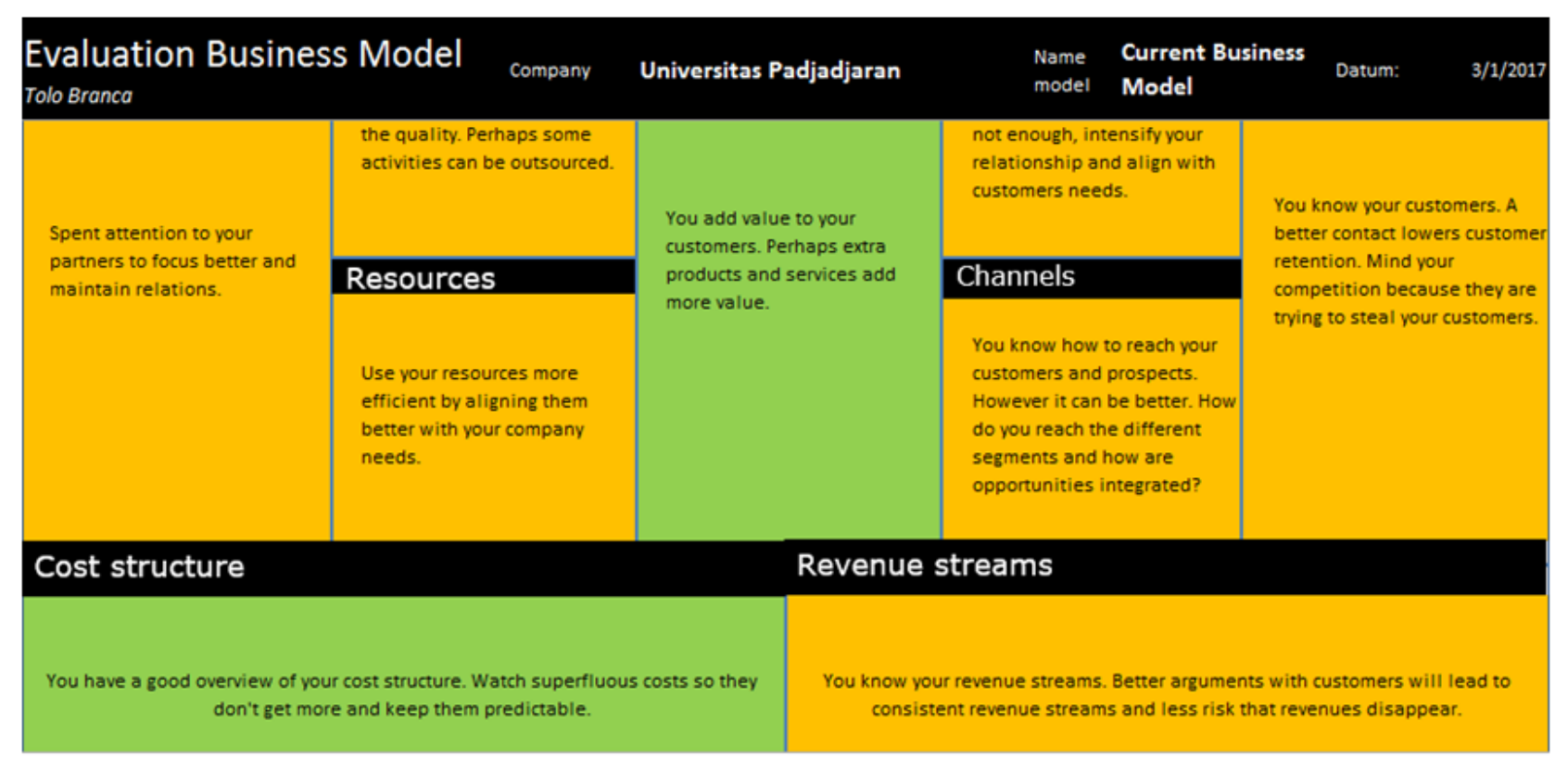

Source: Data field.

Picture-4. Interpretation result of tolo branca V3.3

\subsubsection{Customer Segments}

Based on interpretation and calculation by using tolo branca, customer segments building block colored yellow, as it shown in Picture 5, the graph shows a green color dominant with opportunity value of (4), strength (3.7) and threat value of (1.5). UNPAD customers possessed a low transferring level due to the certain time interval that given by higher education in the service given, students of each program have a certain time of study or limited period, so the possibility of transferring to other HEIs was very small. The strength that UNPAD owned is the segmented customer base, customer was categorized into several ladder starting D IV until S3, besides that the customer also categorized into several groups of academic, business, community, government and media.

\subsubsection{Value Propositions}

Value propositions building block colored green, however in the chart all colors seem to be predominant with the opportunity value of (4.4), strength value (4.3) and threat value of (4). This is because the proposition value of UNPAD conformable to customer's needs, the institution form that provide a lot of study program choices enable customer to choose in accordance to their needs, therefore creating a strong synergy between product and services. The high level of education service, enable UNPAD generating recur revenue due to the form of the product is service, and able to fulfill additional customers' needs for having the authority to open a new study program. Besides that, higher education institution as a hub allows UNPAD to conduct additional work for customers by integrating products that can satisfy customers. However, in the other side, the threat is also huge, the large number of HEIs in Indonesia, provide many substitutions of product and services, so that the competitors threatened to offer a better price or value.

\subsubsection{Channels}

Channels building block colored yellow with a high opportunity value of (4.2) allows UNPAD to develop distribution channels building block. On the graph also shows strength value of (3.7) and threat value of (1). UNPADs' channel is very effective and efficient in reaching the customers because almost every customer segment only uses one distribution channel.

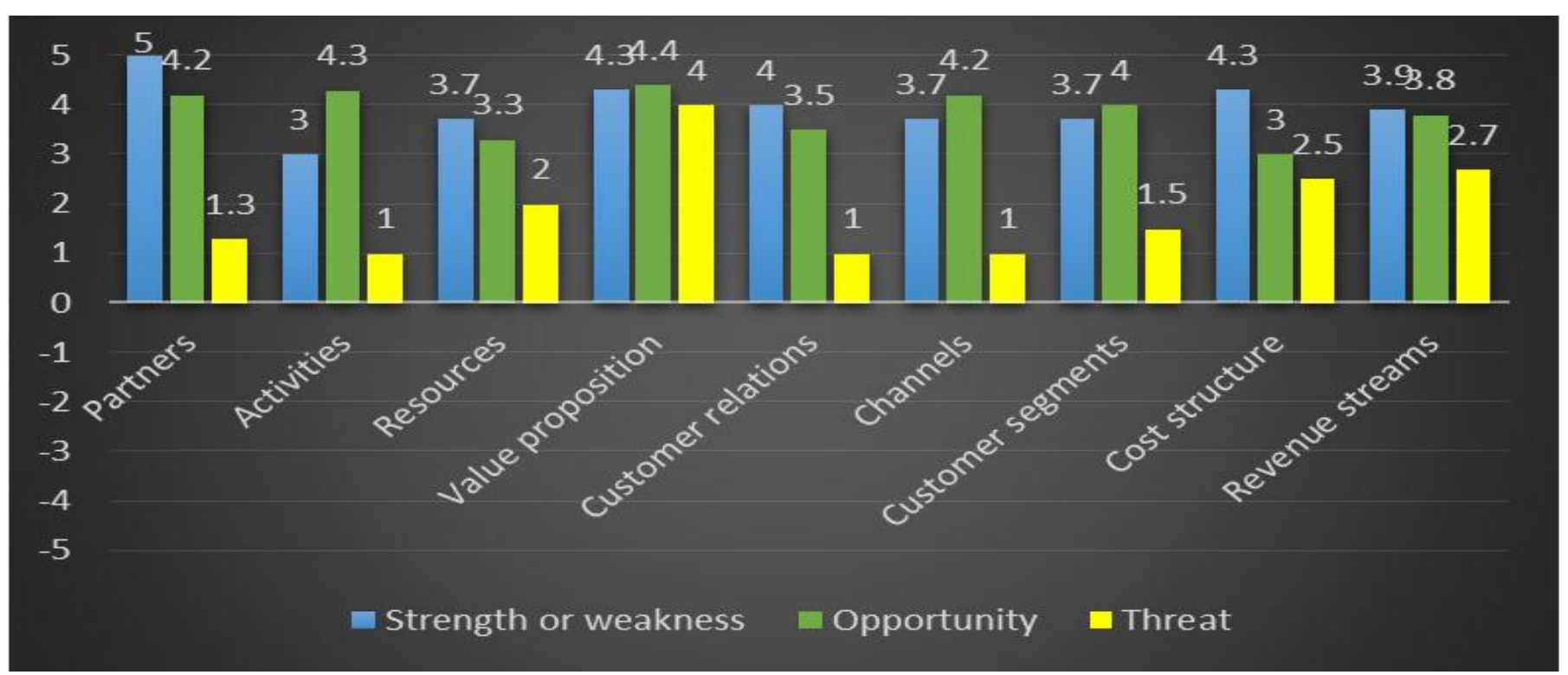

Source: Data field.

Picture-5. Graph of SWOT analysis BMC building block 


\subsubsection{Customer Relationships}

Customer Relationships building block colored yellow, with strength value of (4), opportunity value of (3.5) and threat value of (1). The number indicates the existence of a strong relationship between UNPAD with the local government; by making the local government as research center which supported by the Dean activities representing each district/city area in the West Java Province. Besides that, in order to serve customers' activities, an integrated service unit is available which centered in UNPAD Jatinangor campus to serve the whole customers in one integrated service.

\subsubsection{Revenue Streams}

Revenue streams building block colored yellow, with strength value of (3.9), this happens due to the predictable UNPAD revenue streams, the amount of tuition fee have already been set since the beginning through the single education fee (UKT) mechanism and purchases can be done repeatedly particularly from student customers segment. Besides that, the UNPAD revenue stream is very diversified and sustainable. Opportunity value of (3.8) considered to be high enough to generate new revenue stream through partners with public private partnership scheme. Other concerning issue is the high value of threat (2.7) which threatened the loss of revenue stream. The revenue stream that might be loss is subsidy fund provided by the government to PTN BH.

\subsubsection{Key Resources}

Key resources building block colored yellow, with strength value of (3.7), opportunity value of (3.3) and threat value of (2). The strength of UNPAD resources is the large number of human resources and adequate infrastructure to support a running business model. HEI as the only institution possessing the biggest human resources with magister and doctoral qualifications. However, the big number of threat also indicates that the quality of human resources was threatened by the infrastructure which having depreciation, meanwhile the level of education of human resources mostly still dominated by S2 (magister degree) holder for lecturers and high school graduates for academic staff.

\subsubsection{Key Activities}

Key activities building block colored yellow, with opportunity value of (4.3), strength value of (3) and threat value of (1). Institutional accreditation and study program accreditation indicated that the implementation of civitas academic were relevance. The high opportunity value given the chance to UNPAD main activity by improving efficiency and IT development for the whole research, community empowerment and development (PPM) and learning activities.

\subsubsection{Key Partnership}

Key partnership building block colored yellow, with strength value of (5), opportunity value of (4.2) and threat value of (1.3). The graph presenting a good work relationship with the main partner. Cooperative relationship is very meaningful for UNPAD and its partner. With a lot of key partnership many opportunities would be available to optimize key activities in order to improve revenue stream.

\subsubsection{Cost Structure}

Cost structure building block colored green, with strength value of (4.3), opportunity value of (3) and threat value of (2.5), indicates cost structure incurred is predictable and very relevance to the business model, these also signifies the operational cost of UNPAD business model is very efficient. However, the threat also should be aware, the growth of cost structure which is faster than generated revenue happened due to the human resource expenses changes including remuneration expenses occurred at the beginning of transformation period of UNPAD institution becoming PTN BH (HEI as legal entity).

\subsection{UNPAD Business Model Improvement}

Gassmann et al. (2016) stated that "competitive supremacy of an organization in the future do not determined by an innovative product and process, but by an innovative business model". Picture 5 present UNPAD business model improvement, the pattern used in the improvement of the business model is the combination between free business model pattern with joint fund business model pattern (crowdfunding), also licensing business model pattern as the innovation of UNPAD business model. Crowdfunding business model is the business pattern which divert the funding of a work to the community (public), partially the fund provider is personal or in group who are free to choose the amount of money they wanted to invest (Gassmann et al., 2016). Parties involved in the funding joint usually do not expect any return in terms of money, they tend to expect the work to be done. The combination between free business model pattern and crowdfunding in UNPAD business model improvement would generate profit for UNPAD as well as producing benefit to the customer. Supartini (2010) mentioned that the amount of voluntary donations (endowment) is not specified and usually would be formed on its own based on the image of the future student have. If the image of a higher education institution in a students' mind is negative, automatically they would donate a small amount of fund, and vice versa in accordance to their perception.

Licensing business model related to the creation of intellectual property for customers' benefit by focusing to copyright commercialization which was sold to more than one interested party (Gassmann et al., 2016). Business model innovation conducted based on the SWOT analysis result, which suggested business model improvement to almost the entire BMC building block except value propositions and cost structure, therefore in is important to determine the trigger element of business model improvement. 


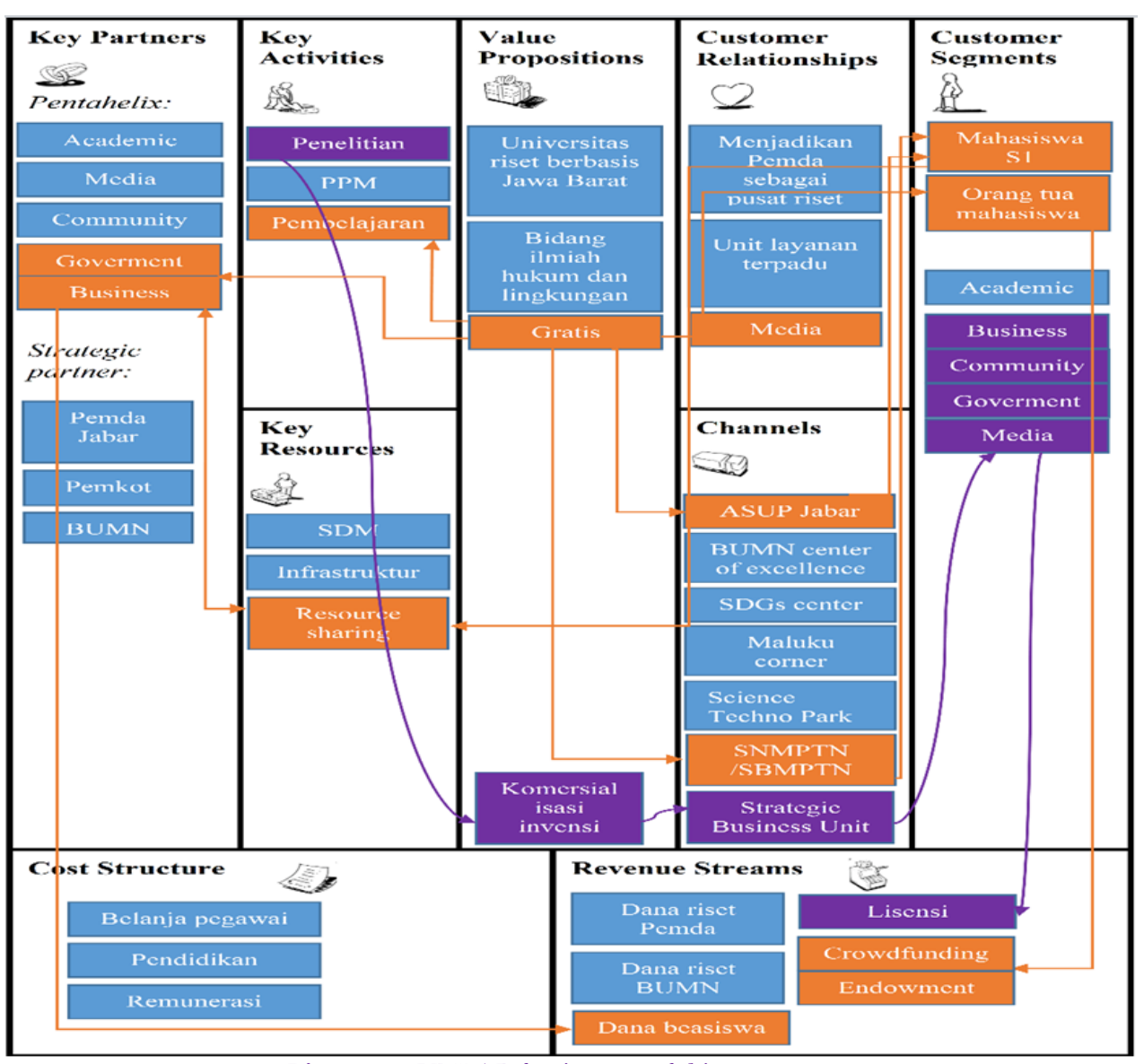

Source: Data field.

Picture-6. UNPAD business model improvement

\subsubsection{Customer Segment Innovation}

Improvement of customer segment building blocks conducted by adopting students' parents as UNPAD customer. In this building block, students' customer segment specialized for undergraduate program students which will obtain the benefit of free tuition fee for a specified period of study time.

\subsubsection{Value Proposition Innovation}

Innovation center of UNPAD business model improvement is the element of value proposition or triggered by quotation, a transformative business model innovation will effect more than one BMC building block. The changes on value proposition building block caused changes in almost all of the other building block namely customer relationship, revenue stream, key resource, key activities and key partnership. A free tuition fee for student customer segment of undergraduate program will improve stringency number, so that UNPAD would obtain the best student input. A good student input will become a qualified graduate in the future and correlated with industry respond to UNPAD graduates. Another innovation of value proposition improvement is invention commercialization which will be ready to be the downstream conducted by customer segment of business, community, government, media and practitioners or individual. Therefore, UNPAD will be more focused in conducting research which ready to be applied without providing any infrastructure nor production cost.

\subsubsection{Channels Innovation}

Improvement to the channels building block conducted by enhance strategic business unit (SBU) to distribute commercialized research results. SBU in terms of limited liability company and the like with separated assets from UNPAD as the parent organization, however could generate revenues for UNPAD.

\subsubsection{Customer Relationship Innovation}

Value proposition changes gave implication to the relationship of UNPAD and its customer. To cultivate such relationship media required as one of the customer relationship element to disseminate information from UNPAD to the customer segment. Such media can be obtained by taking advantage the media of key partners who have been working together with UNPAD during a certain period of time, which is Kompas Gramedia and Mangle magazine, and utilizing social media that has been managed by the directorate of governance and communication UNPAD.

\subsubsection{Revenue Streams Innovation}

The free value proposition gave consequences i.e. loss of tuition fee as one of the source to revenue stream, nevertheless one revenue stream had loss on revenue stream building block it was replaced by three new revenues namely scholarship fund, crowdfunding and endowment. Besides that, intellectual property and invention will also generate a new revenue stream, the license. Andrianto (2016) categorized the strategy of research result commercialization in high education institution becoming new business development (university spin off), joint/alliance, license and direct selling. Other item effecting the revenue stream are business and governments' respond over UNPADs' graduate quality, thus they will make the industry and government more interesting in contribute in terms of special scholarship, in return best graduates for the industry and reliable human resource for the government. 


\subsubsection{Key Resource Innovation}

Sharing Resource on revenue stream building block existing business model diverted into one of the key resource in UNPAD business model improvement. The concept of sharing resource to maximize resources owned by UNPAD as well as to gain the benefit of resources from UNPADs' main partner. Besides that, on business model improvement, UNPAD graduates who financed by government and/or business institutions through special scholarship, will become qualified human resources for the institution.

\subsubsection{Key Activities and Key Partnership Innovation}

Innovation on the key activities and key partnership building block shown no additional activity nor new partner but by maximizing the potential possessed at the moment, revenue stream through intellectual property license will increase both the quality and quantity of a research. Meanwhile in key partnership building block with an adequate number of partners considered to be capable of exploring the partnership potential to maximize UNPAD business model.

\section{Conclusion}

1. PTN BLU (State HEI as public service entity) business model, key activities did not generate any revenue stream for UNPAD because the revenue stream came from APBN (state revenue and expenditure budget) and PNBP (Non Tax State Revenue) are governments' subsidy. These matter appeared in cost structure building block, where the form BLU (public service entity) was a cost structure for the government.

2. PTN BH (State HEI as legal entity) business model is more flexible compared to PTN BLU business model, UNPAD capable of generating other revenue stream and the entire revenue stream admitted as UNPAD revenue.

3. The combination between free business model, crowdfunding and license business model is the intermediary answer between idealism and business for UNPAD in an effort to educate the life of the nation as well as maintain operational sustainability of the higher education institution.

\section{References}

Andrianto, 2016. The strategy of invention commercialization in higher education institution: A treatise of agriculture and environment policy. Agricultural Policy and Environmental Policy Paper, 3(3): 216-227.

Gassmann, K. Frankenberger and M. Csik, 2016. Business model navigator 55 The superior business model that will change your business. Translated by : Waskito S., Jakarta: PT. Elex Media Computindo.

Kemenristekdikti, 2016. Minister of research, technology and higher education regulation No. 126 year 2016 regarding New Students Admission of Undergraduate Program in Public Higher Education Institution, Jakarta (ID): Ministry of Research, Technology and Higher Education (Kemenristekdikti).

Mulders, M. and C. Broek, 2012. Entrepreneurial decision making and the effect on business models. Paper for Entrepreneurial Activities and Support of Entrepreneurs. EFMD, European Foundation for Management Development. Breda, The Netherlands. Osterwalder and Pigneur, 2010. Business model generation. New Jersey (US): John Wiley \& Sons, Inc.

Setneg, 2003. Decree of republic of Indonesia No. 20 year 2003 regarding national education system. Jakarta: State Secretariat.

Setneg, 2012. Decree of republic of Indonesia No. 12 year 2012 regarding higher education. Jakarta: State Secretariat.

Setneg, 2014. Government regulation No. 4 year 2014 regarding organizing and management of higher education. Jakarta: State Secretariat.

Supartini, 2010. Selling product service of higher education institution. Selling product service of higher education institution. Jogjakarta: Jurnal Bahari Jogja, 10(17): 1-9.

\section{Bibliography}

UNPAD, 2016. Rector of University of Padjadjaran Regulation No. 40 Year 2016 Regarding Organization and Working Procedure at University of Padjadjaran, Bandung: UNPAD.

Citation | Budi Mulyana; Arief Daryanto; Agus Purwito (2018). Business Model Development Strategy of Padjadjaran University with Canvas Business Model Approach. Asian Business Research Journal, 3: 1-8.

\section{History:}

Received: 22 January 2018

Revised: 14 February 2018

Accepted: 19 February 2018

Published: 21 February 2018

Licensed: This work is licensed under a Creative Commons

Attribution 3.0 License $(\mathrm{cc}) \mathbf{E}$

Publisher: Eastern Centre of Science and Education
Acknowledgement: All authors contributed to the conception and design of the study.

Funding: This study received no specific financial support.

Competing Interests: The authors declare that they have no conflict of interests.

interests. Transparency: The authors confirm that the manuscript is an honest, accurate, and transparent account of the study was reported; that no vital features of the study have been omitted; and that any discrepancies from the study as planned have been explained.

Ethical: This study follows all ethical practices during writing.

Eastern Centre of Science and Education is not responsible or answerable for any loss, damage or liability, etc. caused in relation to/arising out of the use of the content. Any queries should be directed to the corresponding author of the article. 